\title{
Economic and Social Impacts of Social Entrepreneurship Implementation Service to Community
}

\author{
Yusriadi Yusriadi and Awaluddin \\ Sekolah Tinggi Ilmu Administrasi Puangrimaggalatung, Makassar, Indonesia \\ yusriadi.yusriadi@uqconnect.edu.au, awalstiaprimabone@gmai.com \\ Umi Farida \\ STIE AMKOP, Makassar, Indonesia \\ farida.unm@gmail.com \\ Saidna Zulfiqar bin Tahir \\ Universitas Iqra Buru, Indonesia \\ saidanzulfiqar@gmail.com \\ Misnawati \\ Sekolah Tinggi Ilmu Hukum Pengayoman, Indonesia \\ misnawati_amir@yahoo.com
}

\begin{abstract}
The government's policy to prevent the spread of COVID-19 has limited physical interaction between communities, creating problems for various everyday economic activities. One of which is the existence of a grant given by the Ministry of Research and Technology / National Innovation Research Agency of the Republic of Indonesia for the implementation of community service by guiding the development of microbusinesses in society. This type of research is a descriptive method with a qualitative approach. Data collection was conducted by interviewing eight informants consisting of recipients of the Family Hope Program assistance. Documentation and observation were also carried out to strengthen the data. Data analysis used an interactive model following Milles and Huberman's opinion, namely: data reduction, data presentation, and conclusion drawing.
\end{abstract}

\section{Keywords}

Economic, Entrepreneurship, Community, Poverty, Indonesia

\section{Introduction}

Empowerment activities in Indonesia continue to be carried out, this is done to reduce poverty, one form of policy to improve the economy during the COVID-19 pandemic is in the way of empowering micro businesses carried out by the community. Indonesia, as a developing country with various forms of community activity, has great potential in developing micro-businesses for the welfare of society. Besides that, this will automatically foster economic improvement and prevent the Indonesian nation from an economic recession.

The COVID-19 pandemic is causing economic problems in Indonesia. Social problems arise in the community, especially when the government takes various steps to prevent the spread of COVID-19. It is one of the obstacles for the Indonesian economy, especially in small and medium-sized enterprises or the informal sector. The government's policy to prevent the spread of COVID-19 has limited physical interaction between communities, creating problems for various everyday economic activities. Except that those who move to online platforms can still survive. Therefore, about the handling of COVID-19, the government sees that public consumption will drop dramatically. Public use makes a significant contribution to the economy, which is almost 59\% (Laoli, 2020). 
One form of activity to revive the Indonesian economy is that Micro and Medium Enterprises must be increased to deal with these problems. The type of policy must be optimized by Indonesia to become the foundation of the country's economy (Yusriadi, Sahid, et al., 2019).

Based on this, entrepreneurship must be given a more substantial portion by the state to revive Indonesia's economic activities during the COVID-19 period. The classic obstacle experienced by micro-businesses today is that capital must be overcome. One of which is the existence of a grant given by the Ministry of Research and Technology / National Innovation Research Agency of the Republic of Indonesia for the implementation of community service by guiding the development of micro-businesses in society.

This grant program provides the opportunity for universities to participate in entrepreneurship development to the community so that the mentoring process can be carried out; this will automatically give business actors knowledge to improve human resources. The grant program also provides financial assistance to business actors to continue running their business in this era of COVID-19.

Several studies related to the development of entrepreneurship can improve the country's economy, such as the potential for cooperatives to foster the growth of the real sector. In particular, micro-enterprises can build partnerships in business relationships and network development to expand access and perform the intermediary function of mobilizing and channelling public funds to them (Sarwoko, 2009). Micro-businesses play an essential role in increasing the country's economic growth. With the proportion of the number of microbusinesses that are far above large-scale businesses, micro-businesses significantly contribute to the absorption of informal sector labour and equal distribution of local people's income (Gunawan, 2014).

\section{Methods}

This type of research is a descriptive method with a qualitative approach. This research was conducted in Bone Regency as a form of implementation of a grant by the Ministry of Research and Technology / National Innovation Research Agency of the Republic of Indonesia. Data collection was conducted by interviewing eight informants consisting of recipients of the Family Hope Program assistance, who were deliberately selected according to the study's characteristics. Documentation and observation were also carried out to strengthen the data. The focus of the research is the role of aid recipients in improving the quality of micro-enterprises through participation in poverty reduction efforts. Data analysis used an interactive model following Milles and Huberman's opinion, namely: data reduction, data presentation, and conclusion drawing.

\section{Result and Discussion Impact of Entrepreneurship}

The impact is a measure of the results, both visible and invisible, of an activity, product, or service. Looking for ideas to try, you must first consider what can be created in the construction of a social enterprise. Of course, the impact is positive. We certainly realize that there are social problems that arise in every community, but behind that, there are always business opportunities to create an impact. The impact of the guarantee on the type of social enterprise undertaken (Hasbi et al., 2019). What is more important is understanding the positive effects of any decision taken before deciding to implement the idea, because entrepreneurship is not only for personal gain but can have an impact on those around us.

The implementation of the Community Service (PKM) in Padang Loang Village, China District, Bone Regency, has had several positive impacts on the beneficiary families (KPM) of the Family Hope Program $(\mathrm{PKH})$. One of the effects is the existence of the KPM PKH association or group that can be used as a forum or access to learning and production. This container is the formation of the KPM group, which is part of Ma Barakka's Micro, Small and Medium Enterprises (UMKM). The UMKM was formed jointly by the Service Implementation Team and the KPM KPM PKH Group, the objective of which was to implement the community service. Ma Barakka UMKM has successfully launched household needs as a result of the achievements of the implementation of the community service in the process and the results achieved. These are dish soap products, traditional snack products, and convection products.

Another impact raised by the presence of Ma Barakka's UMKM was the social impact, the financial impact, or the economic impact. As far as the social, economic impact is concerned, these small and mediumsized enterprises have become one of the pillars of household needs, particularly under the current pandemic conditions of Covid-19. Limitation of activities outside the home is an opportunity to carry out useful activities during the implementation of this PKM. With proper health protocols, KPM PKH is once again produced in an active learning circle. 


\section{Economic Impact of the Implementation of Social Procedures for KPM PKH}

Household products and convection produced by KPM PKH have been placed on the market and have generated financial benefits. With these advantages, the cost of spending household goods on KPM PKH is reduced. Ma Barakka's UMKM is one of the wise efforts to reduce poverty in household goods. The independence and production skills of household products owned by the results of PKM training can indirectly reduce the burden on family costs. Purchasing customs have been replaced by production capabilities. Besides, sales profits can also increase family income. It means that KPM PKH has been able to cover household expenditure on revenue from the sale of household products that have been produced. If this activity continues, the benefits will continue to increase daily. So, the hope is, little by little, they 're going to be able to get them from the pre-prosperous line to be prosperous.

Besides, income and profits are not enough, but proper business management is a point of continuity and growth for small and medium-sized enterprises (Kaharuddin et al., 2019). The UMKM, which was formed through this PKM, could produce more products to give more opportunities to add employees. Thus, a smallscale business will become a large-scale business and have a positive impact on other environmental communities around small and medium-sized enterprises (Ansar et al., 2019). The following table shows an increase in KPM's economic condition before and after the implementation of PKM:

Table 2. Data on the increase in the economic condition of KPM

\begin{tabular}{|l|l|l|}
\hline \multirow{2}{*}{ Economic Condition } & \multicolumn{1}{|c|}{ Implementation of The Community Service (PKM) } \\
\cline { 2 - 3 } Shopping Activities & \begin{tabular}{l}
\multicolumn{1}{c|}{ Before } \\
KPM expenditure before \\
entrepreneurship is higher because \\
all household product needs must \\
be purchased, especially laundry \\
soap, which is a necessity in KPM \\
PKH 's kitchen.
\end{tabular} & $\begin{array}{l}\text { Expenditure burdens after UMKM } \\
\text { are reduced due to reduced } \\
\text { expenditure activities due to KPM } \\
\text { PKH's production skills. Besides, } \\
\text { the products produced also have a } \\
\text { high selling value. }\end{array}$ \\
\hline Family Income & $\begin{array}{l}\text { Before entrepreneurship, family } \\
\text { income was lower because KPM } \\
\text { PKH had only relied on her } \\
\text { husband to make a living. They } \\
\text { have no access and no opportunity } \\
\text { to help make money because of } \\
\text { the burden, as wives and mothers } \\
\text { require them to stay at home and } \\
\text { serve. }\end{array}$ & $\begin{array}{l}\text { After joining Ma Barakka's } \\
\text { UMKM, PKH KPM became more } \\
\text { productive in helping husbands } \\
\text { earn money to increase their } \\
\text { family income. This activity } \\
\text { certainly makes the husband } \\
\text { happy, because besides being able } \\
\text { to make money, his nature as a } \\
\text { mother and a wife is still being } \\
\text { carried out. After all, UMKM is in } \\
\text { an environment not far from } \\
\text { home. }\end{array}$ \\
\hline
\end{tabular}

\section{Social Impact of Social Practice Implementation for KPM PKH}

Social entrepreneurship is seen as a solution to accelerate the reduction of unemployment and poverty (Umar, Hasbi, et al., 2019). It is none other than because social entrepreneurship offers advantages over just job creation. Social entrepreneurship has broad benefits because entrepreneurship is not just for employees who are partners, but also for the wider community (Umar, Amrin, et al., 2019).

Social entrepreneurship focuses on community members who are less well off financially or in skills to jointly move businesses to make profits (Rijal et al., 2019). Then the results or benefits are returned to the community to increase their income (Mustafa et al., 2020). By this method, social entrepreneurship is not only capable of creating many jobs. It is also capable of producing a multiplier effect for moving the wheels of the economy and creating social welfare (A et al., 2019).

The formation of the KPM PKH social entrepreneurship is capable of thinking about new ideas and an entrepreneurial spirit. Through the PKM training, the KPM PKH 's thinking has become more positive. In addition to their manufacturing skills, they also appear to be more sensitive to taking advantage of future business opportunities (Yusriadi, Farida, et al., 2019). It is proven that they always come up with business ideas during the discussion process. They are thinking about making more than spending money. The UMKM is a social institution that is the primary social capital in creating a joint venture forum that can provide social and economic added value. 
The following is a table on improving KPM's social status before and after the implementation of PKM:

Table 3. Data on the improvement of KPM's social condition

\begin{tabular}{|c|c|c|}
\hline \multirow{2}{*}{ Economic Condition } & \multicolumn{2}{|c|}{ Implementation of The Community Service (PKM) } \\
\hline & Before & After \\
\hline Motivation and Mindset & $\begin{array}{l}\text { Before PKM, KPM PKH } \\
\text { considered entrepreneurship to be } \\
\text { difficult because, in their view, } \\
\text { entrepreneurship required } \\
\text { significant capital, so that small } \\
\text { people like them with minimal } \\
\text { income would not be able to start } \\
\text { a business. }\end{array}$ & $\begin{array}{l}\text { After PKM and the formation of } \\
\text { social entrepreneurship, KPM } \\
\text { PKH is more aware that an } \\
\text { entrepreneur's start-up is not } \\
\text { always with significant capital. } \\
\text { But can be started with a small- } \\
\text { scale business (UMKM) with } \\
\text { small capital but can provide } \\
\text { benefits for certain slow land. }\end{array}$ \\
\hline $\begin{array}{l}\text { Entrepreneurial } \\
\text { understanding }\end{array}$ & $\begin{array}{l}\text { Before PKM, KPM PKH } \\
\text { considered entrepreneurship to be } \\
\text { taboo because of a lack of } \\
\text { understanding of business } \\
\text { management so that it was at high } \\
\text { risk. They 're afraid the business } \\
\text { they are running won't make a } \\
\text { profit, and they're even going to } \\
\text { make a significant loss. }\end{array}$ & $\begin{array}{l}\text { After PKM and the formation of } \\
\text { social entrepreneurship, KPM } \\
\text { PKH has a better understanding of } \\
\text { the system and entrepreneurship. } \\
\text { They already have a better } \\
\text { understanding of how to look at } \\
\text { real business opportunities and } \\
\text { opportunities so that they are more } \\
\text { courageous in starting a business. }\end{array}$ \\
\hline Social activity & $\begin{array}{l}\text { Before PKM, KPM PKH had } \\
\text { discussions of low quality in its } \\
\text { associations. According to KPM } \\
\text { PKH confession, they are } \\
\text { accustomed to gathering and } \\
\text { sitting together in one place, either } \\
\text { in front of their neighbour's house } \\
\text { or on the main road with others. } \\
\text { But that they make their } \\
\text { association a field of sin, gossip, } \\
\text { share the evil of others, or make } \\
\text { fun of passers-by, right in front of } \\
\text { him. So, what you get is sin, not } \\
\text { income. }\end{array}$ & $\begin{array}{l}\text { With the entrepreneurial } \\
\text { opportunities of PKM and the } \\
\text { formation of Social Entrepreneurs, } \\
\text { KPM can make their association } \\
\text { forum more qualified, do } \\
\text { productive things, produce useful } \\
\text { products, and generate income. } \\
\text { Their gossip activity is reduced } \\
\text { due to the production activities } \\
\text { that must be carried out when the } \\
\text { stock is reduced. }\end{array}$ \\
\hline Employment Opportunity & $\begin{array}{l}\text { Job opportunities for mothers who } \\
\text { have husbands and children are } \\
\text { not like job opportunities for } \\
\text { women who are still girls. Their } \\
\text { access becomes difficult, and the } \\
\text { possibilities are very narrow } \\
\text { because of the nature of women as } \\
\text { housewives is a must. }\end{array}$ & $\begin{array}{l}\text { With the entrepreneurial } \\
\text { opportunities and opportunities } \\
\text { provided by PKM and the } \\
\text { development of this social } \\
\text { strategy, it can open up } \\
\text { employment opportunities for } \\
\text { people who need work, } \\
\text { particularly for homemakers who } \\
\text { have limited access to leave their } \\
\text { homes to look for work. }\end{array}$ \\
\hline
\end{tabular}

\section{Conclusion}

The implementation of social service practices for PKH mothers has a good impact on the community economy. Their production skills can produce products that are able to compete on the market in order to generate financial benefits. With these advantages, the cost of household expenses for KPM PKH mothers is reduced. In addition, sales profits can also increase family income. So, the hope is, little by little, that they will be able to get them out of the pre-prosperous line to be prosperous. The implementation of social service procedures for the community for KPM PKH also has a positive influence on society. There are at least four social impacts generated by this social entrepreneurship, including : 1) Motivation and mindset are formed and able to spur their enthusiasm for entrepreneurship, 2) Understanding entrepreneurship becomes a business opportunity so that they are more courageous in starting a business, 3) Social activities that are only used to gossip and discuss 
the existence of this social entrepreneurship minimize things that are not useful, and 4) Job opportunities are more wide open, especially for under-prosperous homemakers who have limited access to leave the house find a job.

\section{Acknowledgments}

Thanks to the Ministry of Education and Culture, Ministry of Research and Technology/National Research and Innovation Agency Republic Indonesia, Puangrimaggalatung College of Administrative Sciences, Family Hope Program, Regional Government of Bone Regency, and District Government of China.

\section{References}

A, M. A., Siraj, M. L., \& Yusriadi, Y. (2019). The Effectiveness Of The Implementation Of Independent Community Empowerment Programs In Bone District. International Journal of Scientific \& Technology Research, 8(8). https://www.ijstr.org/final-print/aug2019/The-Effectiveness-Of-The-Implementation-OfIndependent-Community-Empowerment-Programs-In-Bone-District.pdf

Ansar, Farida, U., Yahya, M., Yusriadi, Y., \& Bin-Tahir, S. Z. (2019). Institutional economic analysis of bugis merchants in the inter-island trade. International Journal of Scientific and Technology Research, 8(8), 149-152.

Gunawan, H. M. (2014). Pemberdayaan Umkm Dan Upaya Pengentasan Kemiskinan Di Daerah: Sebuah Telaah Konsep.

Hasbi, Sukimi, M. F., Latief, M. I., \& Yusriadi, Y. (2019). Compromise in traditional ceremonies: A case study of the Rambu solo’ ceremony in Toraja regency. Humanities and Social Sciences Reviews, 7(6), $286-291$. https://doi.org/10.18510/hssr.2019.7651

Kaharuddin, A. S., Burhani, A. H., Yusriadi, Y., \& Farida, U. (2019). Innovation And Empowerment Of Fishermen Communities In Maros Regency. International Journal of Scientific \& Technology Research, 8(12), 754-756. www.ijstr.org

Laoli, N. (2020). Sri Mulyani ungkap tiga masalah ekonomi yang disebabkan pandemi Covid-19. Kontan.Co.Id. https://nasional.kontan.co.id/news/sri-mulyani-ungkap-tiga-masalah-ekonomi-yang-disebabkan-pandemicovid-19

Mustafa, D., Farida, U., \& Yusriadi, Y. (2020). The Effectiveness Of Public Services Through E-Government In Makassar City. International Journal of Scientific \& Technology Research, 9(1).

http://www.ijstr.org/final-print/jan2020/The-Effectiveness-Of-Public-Services-Through-E-government-InMakassar-City.pdf

Rijal, S., Haerani, Y., Mayasari, R. E., \& Yusriadi, Y. (2019). The Effectiveness Of Implementation Of Government Regulation Number 41 The Year 2011 On The Development Of Youth Entrepreneurship And Pioneering And The Provision Of Youth Facilities And Infrastructures In Kolaka. International Journal of Scientific \& Technology Research, 8(10). http://www.ijstr.org/paperreferences.php?ref=IJSTR-1019-22680

Sarwoko, E. (2009). Analisis Peranan Koperasi Simpan Pinjam/unit Simpan Pinjam dalam Upaya Pengembangan UMKM di Kabupaten Malang. Jurnal Ekonomi Modernisasi, 5(3), 172-188.

Umar, A., Amrin, Madani, M., Farida, U., Yusriadi, Y., Tamsa, H., Bahtiar, Ansar, Yahya, M., Nurnaningsih, Alam, S., Gunawan, H., Darwis, Sahabuddin, C., Jamaluddin, Misbahuddin, Elpisah, Akbar, Z., Sakkir, G., ... Misnawati, M. (2019). One-stop service policy as a bureaucratic reform in Indonesia. Academy of Strategic Management Journal, 18(2), 1-12.

Umar, A., Hasbi, Farida, U., \& Yusriadi, Y. (2019). Leadership role in improving responsibility of employee’s work in scope of general bureau of government of bulukumba regency. International Journal of Scientific and Technology Research, 8(10), 2019-2021.

Yusriadi, Farida, U., Bin-Tahir, S. Z., \& Misnawati. (2019). Bureaucratic reform of tourism sector public services in Tana Toraja Regency. IOP Conference Series: Earth and Environmental Science, 340(1). https://doi.org/10.1088/1755-1315/340/1/012045

Yusriadi, Sahid, A., Amirullah, I., Azis, A., \& Rahman, A. A. (2019). Bureaucratic reform to the human resouces: A case study on the one-stop integrated service. Journal of Social Sciences Research, 5(1), 6166. https://doi.org/10.32861/jssr.51.61.66

\section{Bibliography}

Yusriadi Yusriad: Head of the Sekolah Tinggi Ilmu Hukum Pengayoman, also a lecturer at the Sekolah Tinggi Ilmu Administrasi Puangrimaggalatung. Doctorate in public administration, and has published several papers at the national and international levels, 2020 as the recipient of community service grants from the the Ministry of 
Education and Culture, Ministry of Research and Technology/National Research and Innovation Agency Republic Indonesia.

Umi Farida: Lecturer at Sekolah Tinggi Ilmu Ekonomi AMKOP, doctorate in public administr, and has published several papers at the national and international levels. Doctorate in public administration, and has published several papers at the national and international levels.

Saidna Zulfiqar bin Tahir: Lecturer at Universitas Iqra Buru, also Chairman of the Institute for Research and Community Service at Universitas Iqra Buru. Doctorate in english education, and has published several papers at the national and international levels.

Misnawati: Lecturer at Sekolah Tinggi Ilmu Hukum Pengayoman, also Expected-Family Program actor, and has published several papers at the national and international levels.

Awaluddin: Lecturer at Sekolah Tinggi Ilmu Administrasi Puangrimaggalatung, also Chairman of the Institute for Research and Community Service at Sekolah Tinggi Ilmu Administrasi Puangrimaggalatung, and has published several papers at the national and international levels. 